\title{
Designing a Learning Environment for Science Education Based on PISA Prospective Teacher: Chemistry Content
}

\author{
Hartono \\ Sriwijaya University \\ Indralaya, Indonesia \\ hartonosains@yahoo.co.id \\ Effendi \\ Sriwijaya University \\ Indralaya, Indonesia \\ Rahmi Susanti \\ Sriwijaya University \\ Indralaya, Indonesia
}

\author{
Riyanto \\ Sriwijaya University \\ Indralaya, Indonesia \\ Ismet \\ Sriwijaya University \\ Indralaya, Indonesia \\ Harrie Eijkelhof \\ Utrecht University \\ Domplein 29, 3512 JE Utrecht, Netherlands
}

\begin{abstract}
This research aimed to produce designed learning environment of chemistry content based on PISA framework at the level secondary school to support student-teacher in learning science. Development research was chosen to achieve the aims of the research. The research involved forty-two students of firstsemester Physics Education Program who took Basic Chemistry Course. The result of teaching showed that learning environment can stimulate students to establish high reasoning to solve the problem. Based on both observation and evaluation process during learning, the students have high activities namely (1) to raise hands to explain of their work results in front of class, (2) to engage in class discussion and have good communication skills, (3) to learn for hearing and analyzing of student explanation, and (4) to learn for changing both concepts and ways in learning science.
\end{abstract}

\section{Keywords: development research, Basic Chemistry, PISA}

\section{I.INTRODUCTION}

In 2012 Indonesian PISA rank for science was 64 from 65 countries referred as Web 1. Education achievement in the world can raise national competitiveness globally in other hands $20 \%$ of the education budget. The PISA rank has to give reflection toward teaching and learning process, especially in the evaluation process. Both teachers and students should be introduced item test PISA model. Reading scientific literacy is important and scientific argumentation as well. Several studies have been done related PISA [1] stated that using online environment of teaching and learning process that facilitate their students to complement argumentation instruction and organizing argumentation activities focussed on related topics may be the potential direction to consider for improving students' PISA scientific competencies. Ref. [2] Concluded that in Finland, teacher demonstration, practical work, the possibility for student drawing conclusions gave good factors to increase high results for PISA science performance. It means that model of teaching Based experiences studies that were conducted in the successive country for PISA, it may implement in Indonesian schools context.

A learning environment is an important thing for students. The learning environment means that condition that students can engage. Stimulating, and enriching learning environment to grow and thrive. In order to achieve this type of rich environment, effective teachers establish and communicate guidelines for expected behavior, monitor students behavior, keep students on task, and infuse humor, care, and respect into the classroom interactions, so as to develop a climate that is conducive to students learning. As a result, research has indicated that a positive learning environment can shape students outcomes in cognitive, motivational, emotional, and behavioral domains.

In this research, a learning environment of science education based on PISA of chemistry contents for student teacher has been developed because of introducing PISA to the student teacher. The problem of research is what characteristics of activities which makes Indonesian student teacher successfully familiar with the nature of the PISA scientific literacy programme and PISA test items are. The aim of the research is to produce a learning environment of science based on the PISA that uses Indonesia context to understanding science concepts. The result of the research will be useful as a model for teaching strategy in introducing PISA at student teachers of university level. 


\section{II.METHOD}

The research used development research to create a learning environment by activities such as analyses, design and producing teaching materials, and evaluation. The first stage, several analyses were conducted at national item tests, the framework of PISA, and syllabi of general chemistry. The second stage, designing was done by modifying PISA item tests that were adjusted with Indonesian contexts. Furthermore, producing teaching materials were such as student worksheets, and PISA like item tests. Finally, there were stages of evaluation as self-evaluation, expert review, one to one, small group, and field test. The research was conducted in odd semester 2014/2015 and involved first semester students who took general chemistry in Physics Program Study both Palembang and Indralaya classes.

\section{III.RESULT AND DISCUSSION}

Analyses of national item tests for secondary school, PISA item test, and syllabi were done. First, basically, national item tests for secondary school is different with PISA test. The national item tests focus on whether students understand, implement, and use the concepts. Unlike PISA tests, students challenge to understand the phenomenon and get problems from those then give solutions in order to answer the problem using certain concepts. Second, framework PISA is important to learn in relationship to introduce PISA to students. As fig. 1 below, science framework of PISA 2015 showed that competencies are central to a framework which indicates that 15 years old students should be able to explain, evaluate/design, and interpret regarding phenomena, scientific inquiry, and data and evidence scientifically. In relation to the competencies, content, knowledge, and attitudes are needed to be integrated to enhance students understanding science in general. Third, Sillaby of general chemistry for Physics Program Study has been revised for meeting 1 through 3. The meetings were modified on contexts, worksheets, item tests, and learning processes to facilitate students learning PISA.

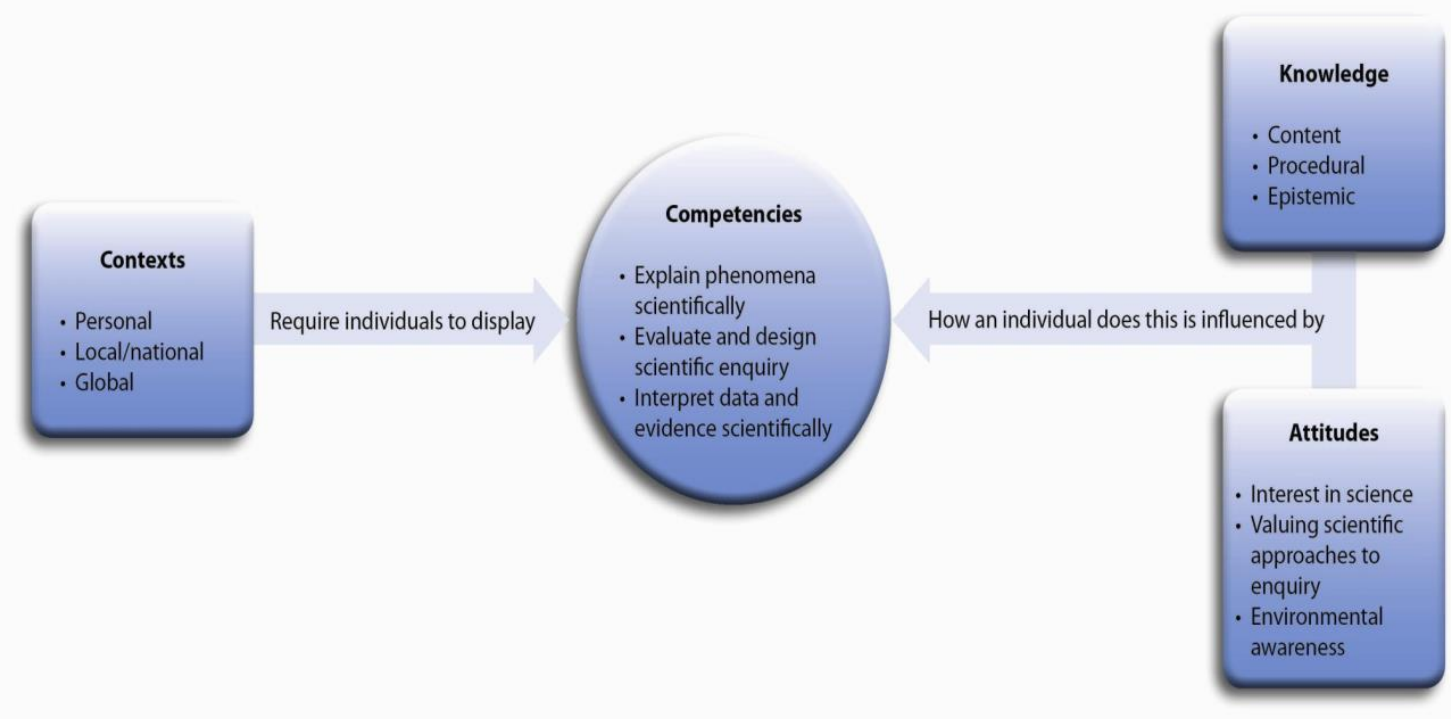

Fig. 1. PISA Science Framework 2015 (Referred as Web 2)

Designing of the learning environment and producing teaching materials that involved the team namely faculty members who have fields as biology, physics and chemistry education. We designed a learning environment that made students be challenged to come up their argumentation/reasoning. A lecturer began the lesson with phenomena in scientific literacy and asked students to raise questions/responds. Furthermore, students in small groups discussed to solve problems at students' worksheet and each group was responsible for presenting their results in front of the class. The end of class, lecturer concluded the lesson. Producing teaching materials are such as students' worksheets and item tests PISA like.

First, the researchers built a learning environment beginning with a model of teaching that facilitated students teacher to solve problems with own their [3]. Stages of learning are such as (1) orientate toward problems/topics, (2) organize students, (3) guide to investigating, (4) develop results and presentation, and (5) analyze and evaluate processes. Ref. [4] stated that problem-based learning is any learning situation in which the problem drives the learning. Students discover they need the information or skills to solve problems. The states are relevant to the research that began the learning with an orientation toward the scientific problems.

Second, the research developed teaching materials such as students teacher worksheets that contained Indonesia Contexts. The problem is like PISA item tests such as; 


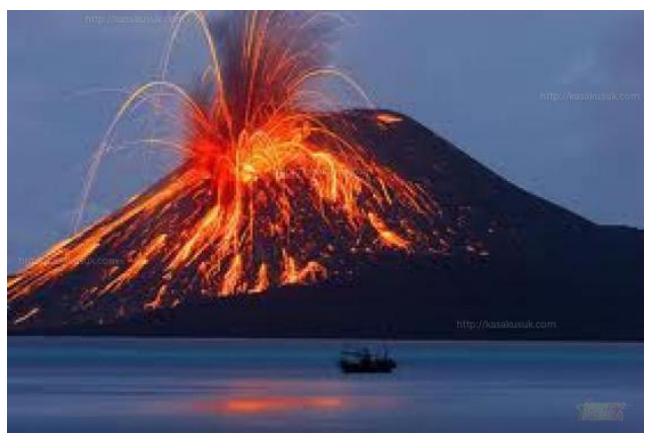

Fig. 2. The Volcano

Indonesia is an archipelago located in the Pacific rings of fire, therefore, still found volcanoes are still active, one of which is Mount Sinabung. Sinabung eruptions caused damage buildings, while larvae and volcanic ash impact on the lives of plants and animals that live in the surrounding area. The phenomenon that could be found from the eruption of Mount Sinabung eg crop yields declined or failed crops, animals and plants are dying, people around to use a mask even found it is difficult to breathe because of residents less oxygen availability, poisoning gases that are emitted by the mountain and the rainwater acidic.

In volcanic earthquakes were accompanied by rain, rainwater is usually acidic. Explain why it could happen.

Students tried to solve the problems in small groups with their own thinking and also to collect data from several resources as gadgets, computers with internet connection, and books as well. The student activities were shown in Figure 3 below. They discussed to solve problems in

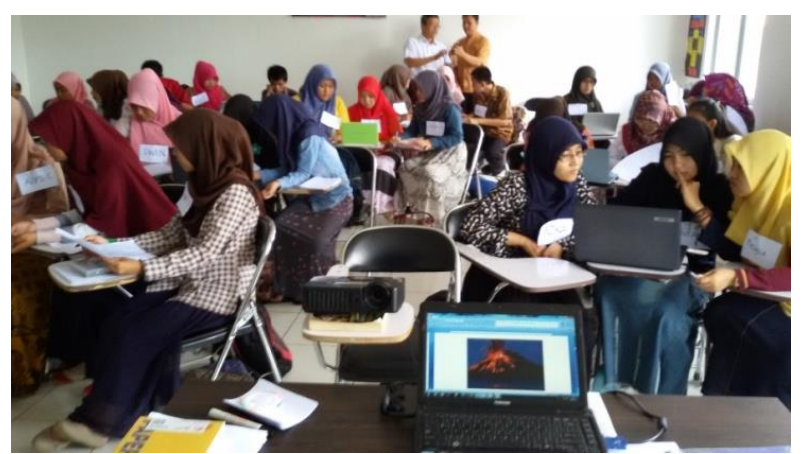

Fig. 3. The Student-Teacher Activities

A worksheet. This learning environment gave students awareness toward classroom environment so they could learn democracy in the group and respect each other.

Student presentation was an important thing for the learning environment (Fig. 4). A little debate occurred while the group presented their work results. The group in charge for presentation explained their work in front of the classroom. They compared their own result each other and the result might be different things. So, in discussion roles of a lecturer was important to decide whether the student answered right or mistake. An example of students' answer was 'the presence of water vapor contained in around mountains would react with a gas of sulfur dioxide then produced sulfurous acid and sulfuric acid that soluted in rainwater. Several groups debated with the products. The student presentation would make a class to be active in terms of raising hands to answer questions and making argumentation. Besides that, almost all the students involved the class and learned in communication skill each other. They were brave to deliver their work to the class.

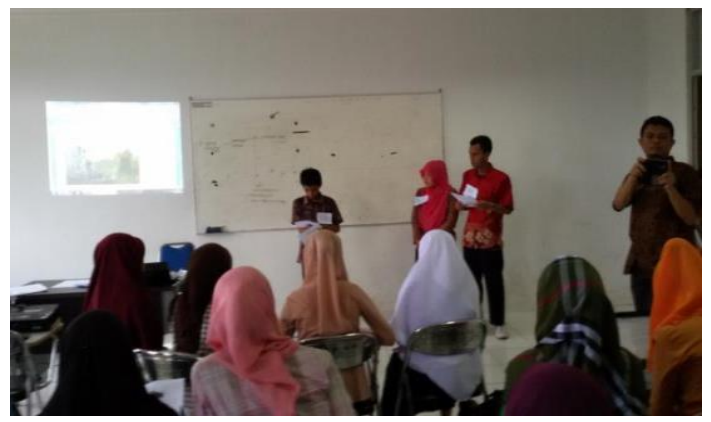

Fig. 4. Class Discussion

Other students learned how to be a good listener. The end of learning, the students changed their concepts if they were in wrong concepts. The lecturer gave final conclusions. So, They knew whether their concept right or wrong. The way of learning science has been practiced and the students have experienced and hopefully, they will teach science in the same way future.

\section{IV.CONCLUSION}

Designing of a learning environment has been done by implementing a model of problem-based learning at general chemistry course on Undergraduate of Physics Education Program both in Indralaya and Palembang classes. The product of a learning environment was not the only model of problem-based learning but also students' worksheet. The learning environment was able to enhance students learning processes and also introduce PISA like item test with Indonesian context to student-teacher.

\section{ACKNOWLEDGEMENTS}

The funding research here was supported by Faculty of Teacher Training and Education Sriwijaya University under grant international collaboration research. The author also greatly appreciates Prof. Harrie Eijkelhof who gave valuable suggestions of PISA item tests and journal resources.

\section{REFERENCES}

[1] Tsai, Chun-Yen.(2014). Improving Students' PISA Scientific Competencies Through On Online Argumentation. International Journal of Science Education, 37(2): $1-19$.

[2] Lavonen, J. \& Laaksonen, S. (2009). Context of Teaching and Learning School Science in Finland: Reflection on PISA 2006 Results. Journal of Research in Science Teaching, 49(8): 922--944.

[3] Zulkardi, Putri, RII, Hartono, Susanti, R., Riyanto, Siahaan, SM, Nawawi E., and Ismet. (2014). Designing a Learning Environment on Mathematics and Science Education Based on PISA for Indonesian Student-Teacher. Research Report. Indralaya: FKIP Sriwijaya University.

[4] Lang, HR \& Evans DN. (2006). Models, Strategies, and Methods for Effective Teaching. Boston: Pearson Education. Inc. 